\title{
Growth Performance, Metabolic Efficiency and Nutrient Utilization of BALB/C Mice Fed with Diet Made from Leftovers from Cocos nucifera Pulp
}

\author{
Omondi Gilbert Ouma ${ }^{1}$, Malala Joel Bonface ${ }^{1,2, ~ *}$, Msanzu Joseph Baya ${ }^{1}$, \\ Anjili Christopher Omukhango ${ }^{3}$, Gicharu Gibson Kamau ${ }^{1}$, Huxley Makonde Mae ${ }^{1}$, \\ Chimbevo Lenny Mwagandi ${ }^{4}$ \\ ${ }^{1}$ Department of Pure and Applied Sciences, Faculty of Applied and Health Sciences, Technical University of Mombasa, Mombasa, Kenya \\ ${ }^{2}$ Directorate of Research and Innovation, Mount Kenya University, Thika, Kenya \\ ${ }^{3}$ Centre for Biotechnology Research and Development, Kenya Medical Research Institute, Nairobi, Kenya \\ ${ }^{4}$ Department of Biomedical Sciences, School of Health Sciences, Kirinyaga University, Kerugoya, Kenya
}

Email address:

jmalala@mku.ac.ke (M. J. Bonface)

${ }^{*}$ Corresponding author

\section{To cite this article:}

Omondi Gilbert Ouma, Malala Joel Bonface, Msanzu Joseph Baya, Anjili Christopher Omukhango, Gicharu Gibson Kamau, Huxley Mokonde Mae, Chimbevo Lenny Mwagandi. Growth Performance, Metabolic Efficiency and Nutrient Utilization of BALB/C Mice Fed with Diet Made from Leftovers from Cocos nucifera Pulp, West Ethiopia. American Journal of BioScience. Vol. 7, No. 1, 2019, pp. 1-6. doi: 10.11648/j.ajbio.20190701.11

Received: January 25, 2018; Accepted: September 5, 2018; Published: February 27, 2019

\begin{abstract}
Shortage of animal feeds as a result of increased demand and competition for scarcely available animal feeds has led to drastic decrease in animal production globally. In Kenya, utilization of various plant parts including leaves, fruits and bark of various plantations is taking center stage. Coconut palm (Cocos nucifera) a member of the pulp family Arecaceae has potential to feed animals from its leftovers after utilization for human food. The study sought to analyze proximate nutritional value composition of Coconut pulp leftovers and its formulated diet as well as in vivo growth performance of BALB/c mice. Formulated coconut pulp leftovers were dried before both phytochemical analysis and in vivo growth performance was determined. The Proximate analysis indicated Coconut pulp leftovers contained; $3.50 \pm 0.22 \%$ crude protein, $34.15 \pm 2.48 \%$ dry matter, $65.85 \pm 3.97 \%$ moisture content, $10.50 \pm 1.2422 \%$ total sugars and $25.00 \pm 0.35 \%$ total fats. Analysis of formulated coconut pulp diet indicated elevated crude protein $14.23 \pm 0.52 \%$, dry matter $35.97 \pm 0.52 \%$ and total sugars $20.47 \pm 4.26 \%$ while moisture content $64.10 \pm 0.50 \%$ and total fats $22.10 \pm 0.50 \%$ declined. In vivo results for the Coconut pulp leftovers application on mice model to ascertain growth performance were as follows; weight gain $0.80 \pm 0.50 \%, \mathrm{SGR} 0.33 \pm 0.29 \%, \mathrm{FCR}$ $241.67 \pm 556.67 \%$ and conditional factor $0.47 \pm 0.12 \%$. For formulated diet it was weight gain $3.90 \pm 3.22 \%, \mathrm{SGR} 1.0483 \pm 0.91 \%$, FCR $28.23 \pm 28.92 \%$ and conditional factor $0.58 \pm 0.04 \%$. The result indicates Coconut pulp leftovers have potential for animal feeds diet formulation.
\end{abstract}

Keywords: Animal Feeds, Coconut Pulp Leftovers, Formulated Diet, Conditional Factor and Arecaceae

\section{Introduction}

Coconut palm (Cocos nucifera) is a member of the palm family Arecaceae, the only accepted of genus Cocos. It is found wild and cultivated in India, Srilanka, Maldives, Middle East, USA, Bamuda and other tropical countries including Kenya, Tanzania, Zanzibar, and Pemba Island.
Traditionally, Coconut palm is known for many uses due to the presence of nutritional values such as; sugars, proteins, vitamins, phytochemical and organic compounds [1-5].

Although the plant has been used for centuries in Kenya, the maximum usage of leftovers from coconut pulp, a byproducts resulting from preparation of coconut milk has not been taken into consideration. The existing gap in the use of 
this by-product coupled with growing reduction in its usage necessitates the need to investigate nutritional and chemical composition. In addition, analysis of anti-nutritional factors and energy composition to ascertain its suitability for use in production of animal feeds is important with increasing feeds shortage due to high demand [6].

In the past decade, there has been no significant increase in animal production due to feeds shortage and/or related problems with digestibility, availability and bioavailability, physical-chemical properties, non-starch polysaccharides (NSP) and absorption in the gastro-intestinal tract [7-9]. Therefore, accurate data on nutritive value for locally available raw materials such as the Coconut pulp need to be analysed to promote cost effective local formulated animal feeds [10-11].

In Kenya, farmers have limited resources available for feeding their animals resulting to food shortage and increased related costs. Therefore, there is need to utilize the locally available raw materials to supplement commercial animal feeds in order to increase animal productivity. One of the cheap and readily available raw materials that can be utilized for feed formulation is the Coconut pulp leftovers. These are the residues left after squeezing coconut milk from the grated coconut meat or pulp. They have been used as a traditional ingredient or feed for ruminants, pigs and poultry for many years and is still a common animal feed component today as either dried or fresh [12].

Coconut pulp leftovers was approved by Food and Drug Association (FDA) and listed in American Feed Control Official (AFCO) in the 1950s for formulating animal feeds [13]. However, this important by-product has not been utilized in Kenya for animal feeds instead thrown away as waste product. Information on chemical composition of these leftovers is scanty athough some studies reveal the presence of octalactone, ethyloctanoate, nonanal, nonanioc acid, decanol, decanal and nonanol, alcohols, ketones, thiols, carboxylic acids, phenols, and esters with short carbon chains [4]. This makes it a valuable raw material source for animal feeds formulation [14]. The studies sought to analyze proximate nutritional value composition of Coconut pulp leftovers and its formulated diet and assess potential to utilize the diet by BALB/C mice.

\section{Materials and Methods}

\subsection{Animal Feeds and Their Preparation}

Mature coconuts bought from Kongowea market, Mombasa County, Kenya. Samples were taken to the Chemistry Laboratory in the Department of Pure and Applied Sciences at the Technical University of Mombasa (TUM) for processing. Briefly, the mature Coconuts were grated then $1 \mathrm{~L}$ hot water added to produce coconut milk. The grated Coconut and leftovers were shade dried for 2 weeks to make pellets using Standard rat pellet (Rate pellets ${ }^{\circledR}$, Unga Feeds Ltd, Kenya) $(50 \% \mathrm{w} / \mathrm{w})$ to ensure palatability of the formulated diets in replicates. Proximate composition analysis of the diets was determined using the standard methods of the Association of Official Analytical Chemists [1]. The formulated feeds were taken to Kenya Medical Research Institute (KEMRI) in the Center for Biotechnology Research and Development (CBRD) for in vivo experiments.

\subsection{Animals}

Male BALB/C mice (3 - 4 weeks old) obtained from Kenya Medical Research Institute (KEMRI) animal house, housed in clean polypropylene cages and maintained under standard laboratory conditions; temperature $25 \pm 2^{\circ} \mathrm{C}, 60 \%$ humidity and a natural light-darkness cycle 12/12 hours for 10 days prior to experiment. They were then fed with standard rat pellets formulated feed, leftovers from coconut pulp and water ad libitum. All in vivo experiments with mice were performed according to the established bioethical standards of the KEMRI's Scientific and Ethics Review Unit (SERU).

\subsection{Experimental Design}

The BALB/C mice were randomly allocated into three experimental groups of six mice per group. The animals were fed with standard pellets (Rate pellets ${ }^{\circledR}$, Unga Feeds Ltd, Kenya) (Group 1), leftovers from coconut pulp pellets (Group 2 ), pellets from leftovers from coconut pulp mixed with standard rat pellets (Groups 3) and water ad libitum. Before and after the start of the experimental period (70 days), growth performance and nutrient utilization were assessed using established procedures [18] as follows; Body mass gain $(\mathrm{BMG})=[(\mathrm{FBM})-(\mathrm{IBM})] / \mathrm{IBM}] \times 100$, Specific growth rate $(\mathrm{SGR} \%$ per day $)=[(\mathrm{FBM})-(\mathrm{IBM}) /$ number of trial days $] \mathrm{x}$ 100 , Feed conversion ratio $(\mathrm{FCR})=$ Dry feed fed $(\mathrm{g}) / \mathrm{BMG}(\mathrm{g})$, Protein efficiency ratio $(\mathrm{PER})=$ fresh BMG $(\mathrm{g}) /$ Crude Protein (CP) fed (g), Protein productive value $(\mathrm{PPV}) \%=[($ final mice body protein in $\mathrm{g}$ - initial mice body protein in $\mathrm{g}$ )/total protein consumed in $\mathrm{g}$ ] x 100, Food consumption $(\mathrm{FC})$ per day $=$ Total amount of food consumed by mice in the experimental period/duration of the trial days and Apparent lipid conversion $(\mathrm{ALC}) \%=[$ (final mice body lipid in $\mathrm{g}$ - initial mice body lipid, g)/total crude lipid consumed in g] x 100. At the end of the experimental period (70 days), the animals were fasted for about 4 hours with free access to water and exsanguinated under Sagatal ${ }^{\circledR}$ anesthesia. $2 \mathrm{~mL}$ of blood sample was collected for determination of haematological and biochemical parameters and blood metabolites using a Retroflon ${ }^{\circledR}$ Plus automated analyzer.

\subsection{Data Analysis}

Qualitative and quantitative parameters such as haematological parameters, blood related metabolites, growth performance, body mass gain and food consumption were analyzed using mean separation by GenStat program [19]. Mean separation was done through Fischer least significance difference. Comparisons between two treatments were done by means of unpaired Student's t-test and significance established by ANOVA at $95 \%$ confidence level. 


\section{Results}

The proximate nutritional value composition of coconut pulp leftovers diet formulation reported low quality in comparison to formulated standards.

Table 1. Proximate compositional analysis of different animal feeds used in feeding of BALB/c mice.

\begin{tabular}{llll}
\hline \multirow{2}{*}{ Parameter } & Animal Feed used & & \\
\cline { 2 - 4 } & Standard rat Pellets & Coconut leftovers & Formulated diet \\
\hline Dry Mater & $58.23^{\mathrm{a}} \pm 0.76$ & $34.15^{\mathrm{b}} \pm 2.48$ & $35.97^{\mathrm{b}} \pm 0.52$ \\
Crude Proteins & $13.17^{\mathrm{a}} \pm 0.52$ & $3.50^{\mathrm{b}} \pm 0.23$ & $14.23^{\mathrm{a}} \pm 0.52$ \\
Moisture content & $41.63^{\mathrm{a}} \pm 1.04$ & $65.85^{\mathrm{b}} \pm 3.97$ & $64.10^{\mathrm{b}} \pm 0.50$ \\
Total sugars & $13.37^{\mathrm{a}} \pm 0.63$ & $10.50^{\mathrm{b}} \pm 1.24$ & $20.47^{\mathrm{c}} \pm 4.26$ \\
Total fats & $2.57^{\mathrm{a}} \pm 0.63$ & $25.00^{\mathrm{b}} \pm 0.35$ & $22.10^{\mathrm{c}} \pm 0.50$ \\
\hline
\end{tabular}

Values are given as means of three replicates \pm Standard error of the mean (SEM). Values appended by different small letters within a row are significantly different $(\mathrm{P}<0.05)$
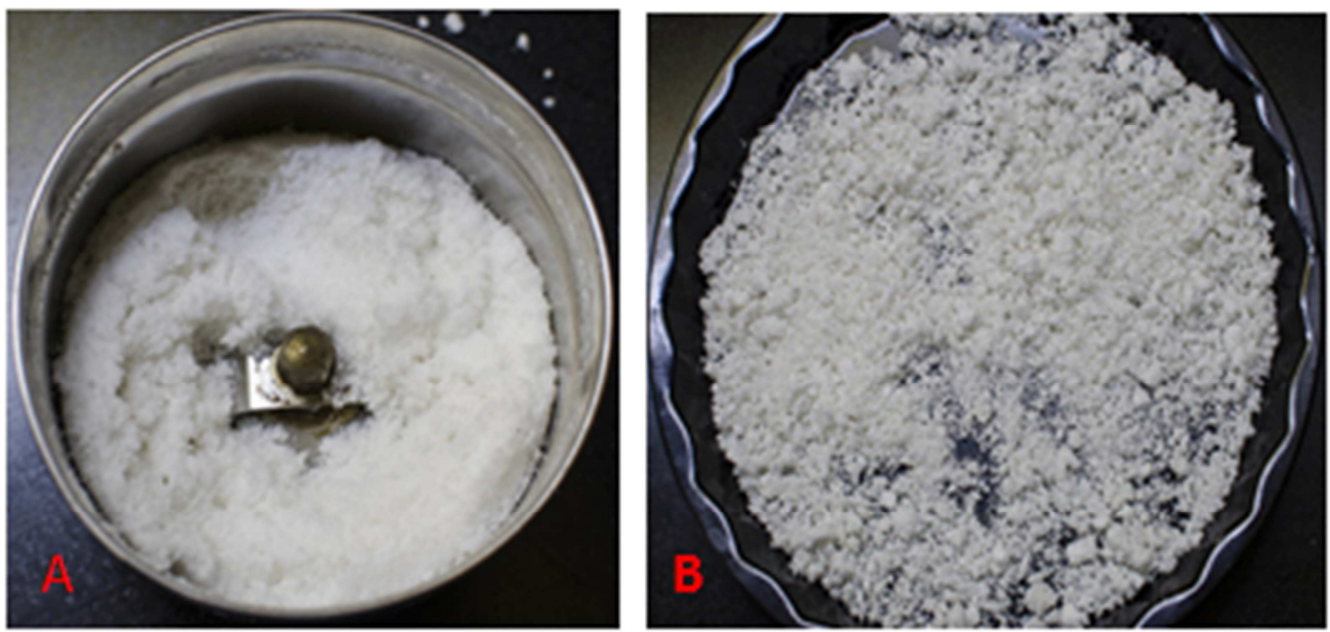

Figure 1. (a) Coconut pulp after grating but before squeezing the coconut milk (b) Leftovers from Coconut after the milk has been squeezed.

For the growth performance and efficiency of formulated diets in BALB/C mice, the effect of experimental Coconut diets on growth performance of BALB/C mice are shown in table 2 and figure 1 below.

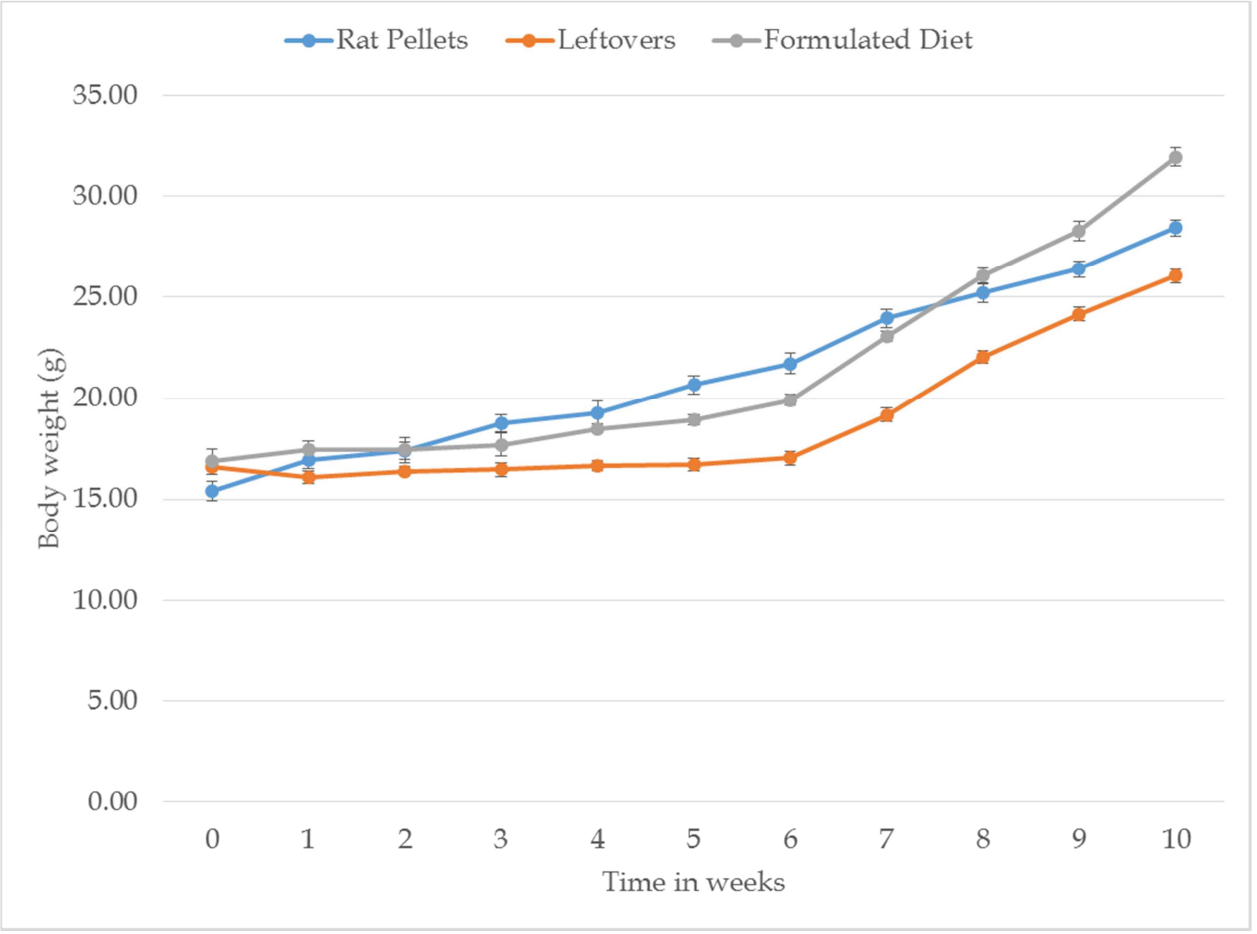

Figure 2. Changes in body weight of $B A L B / C$ mice after feeding with different experimental feeds. 
Omondi Gilbert Ouma et al:: Growth Performance, Metabolic Efficiency and Nutrient Utilization of BALB/C Mice Fed with Diet Made from Leftovers from Cocos nucifera Pulp, West Ethiopia

Table 2. Growth performance and nutrient utilization in BALB/C mice fed with the experimental diets for 28 days.

\begin{tabular}{llll}
\hline \multirow{2}{*}{ Growth Parameter } & Animal Feed used & \\
\cline { 2 - 4 } & Standard rat Pellets & Coconut left overs & Formulated feed \\
\hline IBM & $15.40^{\mathrm{a}} \pm 0.48$ & $16.60^{\mathrm{a}} \pm 0.38$ & $16.87^{\mathrm{a}} \pm 0.65$ \\
FBM & $28.43^{\mathrm{a}} \pm 0.39$ & $26.07^{\mathrm{b}} \pm 0.33$ & $31.93^{\mathrm{c}} \pm 0.47$ \\
\%BMG & $13.03^{\mathrm{a}} \pm 1.45$ & $10.53^{\mathrm{b}} \pm 2.50$ & $15.06^{\mathrm{a}} \pm 3.2296$ \\
\%SGR & $0.93^{\mathrm{a}} \pm 0.51$ & $0.33^{\mathrm{b}} \pm 0.29$ & $1.05^{\mathrm{a}} \pm 0.9173$ \\
FCR & $30.70^{\mathrm{a}} \pm 14.43$ & $41.67^{\mathrm{b}} \pm 556.67$ & $28.23^{\mathrm{a}} \pm 28.92$ \\
CF & $0.54^{\mathrm{a}} \pm 0.11$ & $0.47^{\mathrm{a}} \pm 0.12$ & $0.58^{\mathrm{a}} \pm 0.04$ \\
PER & $1.96^{\mathrm{a}} \pm 0.12$ & $1.07^{\mathrm{b}} \pm 0.17$ & $0.19^{\mathrm{c}} \pm 0.04$ \\
PPV & $0.86^{\mathrm{a}} \pm 0.06$ & $0.46^{\mathrm{b}} \pm 0.16$ & $0.02^{\mathrm{b}} \pm 0.01$ \\
ALC & $0.09^{\mathrm{b}} \pm 0.01$ & $0.04^{\mathrm{a}} \pm 0.02$ & $0.03^{\mathrm{a}} \pm 0.09$ \\
\hline
\end{tabular}

Values are given as means of six replicates \pm Standard error of the (SEM). Values appended by different small letters within a row are significantly different ( $p$ $<0.05$ ). Key: IBM, Initial body mass; FBM, Final body mass; BMG, Body mass gain; SGR, Specific growth rate; MGR, FCR, Feed conversion ratio; PER, Protein efficiency ratio; PPV, Protein productive value; ER, Energy retention; ALC, Apparent lipid conversion; CF, Conditional factor.

The experiment recorded zero mortality rate with highest weight gain and SGR observed in mice fed on diet 3 (formulated diets), followed by diet 1 (standard rat pellets) and diet 2 (coconut pellets). Feed conversion was the most efficient in mice fed on diet 3 compared to diet 1 and 2. Condition factor of mice fed on diet 3 was higher in comparison to diet 1 and 2.

Table 3. Haematological parameter of BALB/C mice fed with the experimental diets for 10 weeks (70 days).

\begin{tabular}{|c|c|c|c|c|}
\hline Parameter & Rat Pellets & Coconut Leftovers & Formulated Feed & Reference Range \\
\hline $\mathrm{HB}(\mathrm{g} / \mathrm{dL})$ & $12.05 \pm 0.32$ & $11.48 \pm 0.13$ & $11.95 \pm 0.98$ & $12.60-20.50$ \\
\hline $\mathrm{WBC} \times 10^{9} / \mathrm{L}$ & $8.88 \pm 0.109$ & $8.22 \pm 160$ & $7.85 \pm 189.24$ & $3.48-14.03$ \\
\hline $\mathrm{RBC} \times 10^{12} / \mathrm{L}$ & $7.55 \pm 1.25$ & $6.72 \pm 1.21$ & $6.94 \pm 1.27$ & $6.93-12.24$ \\
\hline HCT/PCV (\%) & $46.781 \pm 1.22$ & $49.96 \pm 0.74$ & $41.94 \pm 2.52$ & $42.10-68.30$ \\
\hline $\mathrm{MCV}(\mathrm{FL})$ & $54.30 \pm 1.64$ & $49.30 \pm 0.91$ & $52.78 \pm 1.58$ & $50.70-64.40$ \\
\hline $\mathrm{MCH}(\mathrm{pg})$ & $17.37 \pm 1.30$ & $16.87 \pm 1.10$ & $16.17 \pm 4.5$ & $13.20-17.60$ \\
\hline $\mathrm{MCHC}(\mathrm{g} / \mathrm{dL})$ & $27.82 \pm 1.24$ & $26.82 \pm 1.40$ & $27.01 \pm 1.78$ & $23.30-32.70$ \\
\hline $\operatorname{PLT} \times\left(10^{12} / \mathrm{L}\right)$ & $651.17 \pm 60.01$ & $544.50 \pm 45.39$ & $595.04 \pm 78.54$ & $420.00-1698.00$ \\
\hline Neutrophils (\%) & $28.74 \pm 1.18$ & $26.41 \pm 0.95$ & $27.12 \pm 1.09$ & $9.86-39.11$ \\
\hline Lymphocytes (\%) & $54.72 \pm 0.58$ & $52.56 \pm 0.48$ & $53.79 \pm 1.54$ & $50.00-96.00$ \\
\hline Monocytes (\%) & $7.50 \pm 0.21$ & $6.67 \pm 0.20$ & $6.98 \pm 1.05$ & $3.29-12.48$ \\
\hline Eosinophils (\%) & $2.17 \pm 0.11$ & $1.83 \pm 0.13$ & $2.01 \pm 0.67$ & $0.11-4.91$ \\
\hline Basophils (\%) & $0.20 \pm 0.05$ & $0.15 \pm 0.03$ & $0.25 \pm 0.47$ & $0.00-1.84$ \\
\hline Abs Neutrophils & $5.15 \pm 0.24$ & $4.15 \pm 0.17$ & $4.87 \pm 0.19$ & $0.00-3.83$ \\
\hline Abs Lymphocytes & $3.33 \pm 0.11$ & $3.00 \pm 0.07$ & $2.84 \pm 0.09$ & $2.22-9.83$ \\
\hline Abs Monocytes & $0.70 \pm 0.03$ & $0.63 \pm 0.04$ & $0.68 \pm 0.07$ & $0.21-1.25$ \\
\hline Abs eosinophils & $0.22 \pm 0.04$ & $0.13 \pm 0.02$ & $0.18 \pm 0.05$ & $0.01-0.49$ \\
\hline Abs basophiles & $0.00 \pm 0.0$ & $0.00 \pm 0.00$ & $0.01 \pm 0.01$ & $0.00-0.18$ \\
\hline
\end{tabular}

Reference ranges are from Charles River research model [20]

From above data, all tested parameters were within the reference range except for Haemoglobin (HB); Coconut leftovers (11.48 \pm 0.13$)$ and formulated feeds $(11.95 \pm 0.98)$ which were below the standard while Abs Neutrophils; Rat Pellets (5.15 \pm 0.24$)$, Coconut leftovers $(4.15 \pm 0.17)$ and formulated feeds $(4.87 \pm 0.19)$ were all above the reference range. Blood Biochemistry for renal, liver and lipid profile function for the $\mathrm{BALB} / \mathrm{C}$ mice on experimental diet showed that majority of blood metabolite parameters were within the reference range after 70 days (Table 4) below. Albumin; Rat pellet $(26.80 \pm 0.90)$, Coconut leftovers $(25.30 \pm 0.62)$ and formulated feed $(26.02 \pm 0.57)$ and Cholesterol; Rat pellet (4.37 \pm 0.20$)$, Coconut Leftovers $(3.47 \pm 0.06)$ and Formulated feed $(4.85 \pm 0.67)$ were all below their respective reference ranges.

Table 4. Blood biochemistry for renal function, liver function and lipid profile in BALB/C mice fed with experimental diets for 10 weeks (70 days).

\begin{tabular}{llll}
\hline Blood Metabolites & Rat Pellets & Coconut leftovers & Formulated Feed \\
\hline Total Proteins (g/dL) & $53.33 \pm 1.56$ & $49 \pm 0.83$ & $55.24 \pm 1.28$ \\
Albumin (g/dL) & $26.80 \pm 0.90$ & $25.30 \pm 0.62$ & $26.02 \pm 0.57$ \\
Globulin (g/dL) & $30.70 \pm 1.61$ & $27.37 \pm 1.00$ & $27.98 \pm 0.66$ \\
Glucose (g/dL) & $59.88 \pm 2.87$ & $59.38 \pm 3.52$ & $62.64 \pm 6.17$ \\
Triglycerides (g/dL) & $1.91 \pm 0.04$ & $2.17 \pm 0.07$ & $2.75 \pm 0.12$ \\
Cholesterol (g/dL) & $4.37 \pm 0.20$ & $3.47 \pm 0.06$ & $4.85 \pm 0.67$ \\
HDL Cholesterol (g/dL) & $1.24 \pm 0.07$ & $0.93 \pm 0.03$ & $1.87 \pm 0.89$ \\
Sodium (mMol/L) & $145.43 \pm 1.06$ & $145.43 \pm 1.17$ & $147.54 \pm 1.66$ \\
Chloride (meq/L) & $115.67 \pm 0.64$ & $117.47 \pm 0.70$ & $116.77 \pm 1.67$ \\
Potassium (meq/L) & $4.62 \pm 0.12$ & $4.62 \pm 0.13$ & $5.01 \pm 0.37$ \\
\hline
\end{tabular}




\begin{tabular}{lllll}
\hline Blood Metabolites & Rat Pellets & Coconut leftovers & Formulated Feed & Reference Range \\
\hline ALT (IU/L) & $45.2 \pm 2.17$ & $41.20 \pm 1.91$ & $44.33 \pm 1.77$ & $41.00-131.00$ \\
AST (IU/L) & $46.03 \pm 1.20$ & $43.53 \pm 0.87$ & $44.67 \pm 1.67$ & $28.00-191.00$ \\
ALKP (IU/L) & $170.17 \pm 3.35$ & $156.00 \pm 1.91$ & $147.44 \pm 2.89$ & $118.00-187.00$ \\
\hline
\end{tabular}

Reference ranges are from Charles River research model, (2012)

\section{Discussion}

Haematological and blood biochemistry parameters experiments in $\mathrm{BALB} / \mathrm{C}$ mice fed on experimental diet showed great potential for utilization of Coconut leftovers for formulation of animal feed diets. Comparison between proximate composition and established known reference range showed no significant difference which was attributed to downstream processes such as; processing, drying or storage methods used. In this regard, establishing a standard Coconut production and processing criteria will improve nutritional value composition not only for utilization for human food but also formulation of animal feed diet. The ability of the experiment to record zero mortality rate coupled with good growth performance was evidence for stable formulated Coconut pulp diet constituting the essential nutritional components for BALB/C mice survival. Decrease in weight gain, FCR and SGR at a high level of dietary supply was corrected to protein/energy ratio which decreased with increase in dietary supply. This could suggest the need to ensure proper protein/energy ratio regulated by animal's metabolism processes. In animals including Mice, proteins are essential nutrients and must be supplied adequately to ensure proper growth and development. During starvation period, animal bodies utilize readily available proteins in the adipose tissues for energy. The findings agree with other studies [15] which found out that it is important to balance protein/energy ratio in any formulated animal diet to enhance growth and development. Coconut meal contains tannins as major antinutritional factors [17] and high fiber [18], which limits its utilization. It was envisaged that by reducing level of tannins, Coconut meal could represent a cheap and valuable source of both energy and protein in diet of tilapia [17]. Growth of Mice depends on interaction between biotic and abiotic factors known as the Conditional factor which is an indicator of Mice physiological condition. Studying Conditional factors helps reveal growth progress of Mice at all stages to ensure successful development [18]. Therefore, in the current study, Conditional factor seemed comparable and adequate indicating the potential of utilizing Coconut pulp leftovers in formulation of animal feeds.

\section{Conclusion and Recommendations}

From the study, Coconut pulp has the potential to be utilized in the formulation of animal feeds as revealed by the in vivo experiment on $\mathrm{BALB} / \mathrm{C}$ mice. It is important to move this research step ahead by determining the concentration of blood related metabolites after feeding BALB/C mice with formulated feeds to ascertain the health of mice. In addition, determining digestibility Coefficient and assessing its effect on the protein content of formulated diet will provide more information on balancing protein/energy ratio during formulation. Best production and processing methods of Coconut meal need to be determined for consistent quality of product.

\section{Acknowledgements}

The Department of Pure and Applied Sciences, Technical University Mombasa (TUM) is highly indebted to the funding of this study. $\left({ }^{\dagger}\right)$ Omondi Gilbert Ouma deceased on February 19 2017. He did the entire laboratory work for this project at the Kenya Medical Research Institute (KEMRI) and it was our unanimous view to include him in the Manuscript as the $1^{\text {st }}$ author.

\section{Conflict of Interest}

All authors declare no conflict of interest in this project.

\section{References}

[1] AOAC. Official Methods of Analysis. Association of Official Analytical Chemists, Washington DC. 2000.

[2] FAO. Poultry feeding in tropical and sub-tropical countries. Food Agricultural Organization (FAO). Agriculture Development paper 82. F AO, Rome. 22pp. 1967.

[3] Fife BF. Coconut cure: preventing and treating common health problems with coconut. Piccadily Books. Colorado Springs, CO, USA. 2005.

[4] Gohl B. Tropical feeds. Animal Production and Health Division. 1975. Food Agricultural Organization (FAO) Rome. Paper 98.

[5] Kadere T. T; R. K. Oniango, P. M. Kutima and S. M. Njoroge 2009; Production, Marketing, and economic importance of Mnazi and other coconut based products in Kenya; Research journ. Agric. 7 Bio. Sciences; 5(5) 815-822.

[6] McDonald P, Edwards RA, Greenhalg JFD. Animal nutrition. $3^{\text {rd }}$ ed. Longman, London and Newyork. 1981.

[7] Payne RW, Murray DA, Harding SA, Baird DA, Soutar DM. an introduction to GenStat for windows, $14^{\text {th }} \mathrm{ed}$. VSN International, Hemel Hempstead, UK. 2011.

[8] FAO. Poultry feeding in tropical and sub-tropical countries. Food Agricultural Organization (FAO). Agriculture Development paper 82. F AO, Rome. 25pp. 1995.

[9] P. McDonald, R. A. Edwards, and J. F. D. Greenhalgh. $1^{\text {st }}$ ed. Longman Group Limited, London (1977). ISBN 10: 0582441579 ISBN 13: 9780582441576 
[10] Mwachiro, E. C and Gakure, R. W. 2011. Factors Affecting the Coconut Industry from Benefitting the Indigenous Communities of Kilifi District, Kenya. International Journal of Humanities and Social Science; 1(4), 209-218.

[11] Jagadi, M. M, Rundgren, M. and Ogle, R. B. (2016). Chemical characterisation and nutrient evaluation of some Tanzanian plant protein feedstuffs Department of Animal Nutrition and Management. Journal of Swedish University of Agricultural Sciences; 23(19), 143-167.

[12] Jayathilakan, K. Khudsia S, Radhakrishna, K and Bawa, A. S. (2012). Utilization of byproducts and waste materials from meat, poultry and fish processing industries: a review. International Journal of Food Science Technology; 49(3): 278-293.

[13] Food and Drug Association (FDA). 1955. Ingredients and additives. Available online.

[14] Kedar Nath Mohanta, Sankaran Subramanian and Veeratayya Sidweerayya Korikanthimath (2013). Evaluation of Different Animal Protein Sources in Formulating the Diets for Blue Gourami, Trichogaster Trichopterus Fingerlings; $10.4172 / 2155-9546.1000164$
[15] Johnny O. Ogunji and Manfred Wirth (2018). Alternative protein sources as substitutes for fishmeal in the diet of young tilapia Oreochromis Niloticus. Institute of freshwater ecology and Inland fisheries; 43(13), 1312-1320.

[16] Mukhopadhyay Y. and Ray R. (2009). Effect of fermentation on the nutritive value of sesame seed meal in the diets for rohu, Labeo rohita (Hamilton), fingerlings. International Journal of Aquaculture Nutrition; 5(4):229-236.

[17] Swick, R. A. (1999). Considerations in using protein meals for poultry and swine. American Soybean Association, Technical Bulletin. 19pp.

[18] Liu ML, Mars WM, Zarnegar R, Michalopoulos GK (1994) Collagenase pretreatment and the mitogenic effects of hepatocyte growth factor and transforming growth factoralpha in adult rat liver. Hepatology 19: 1521-1527. 